\title{
Correction to: The burden of comorbidity in people with chronic kidney disease stage 3: a cohort study
}

Simon D. S. Fraser ${ }^{1 *}$, Paul J. Roderick ${ }^{1}$, Carl R. May ${ }^{2}$, Natasha Mclntyre ${ }^{3}$, Christopher Mclntyre ${ }^{4}$, Richard J. Fluck ${ }^{3}$, Adam Shardlow ${ }^{4}$ and Maarten W. Taal ${ }^{4}$

\section{Correction to: BMC Nephrol 16, 193 (2015) https://doi.org/10.1186/s12882-015-0189-z}

Following publication of the original article [1], the authors identified an error in Fig. 1. The labels for ' 3 or more comorbidities' and ' 0 or 1 comorbidity' were incorrectly placed and should be reversed on this Kaplan Meier plot (i.e. people with 3 or more comorbidities experienced poorer survival and people with 0 or 1 comorbidity experienced better survival). The correct figure is given below.

\footnotetext{
Author details

${ }^{1}$ Academic Unit of Primary Care and Population Sciences, Faculty of Medicine, University of Southampton, South Academic Block, Southampton General Hospital, Tremona Road, Southampton, Hampshire SO16 6YD, UK. ${ }^{2}$ Faculty of Health Sciences, University of Southampton, Southampton, UK. ${ }^{3}$ The Department of Renal Medicine, Royal Derby Hospital NHS Foundation Trust, Derby, Derbyshire, UK. ${ }^{4}$ Division of Medical Sciences and Graduate-Entry Medicine, University of Nottingham, Derby, UK.
}

Published online: 21 December 2020

\section{Reference}

1. Fraser SDS, et al. The burden of comorbidity in people with chronic kidney disease stage 3: a cohort study. BMC Nephrol. 2015;16:193. https://doi.org/ 10.1186/s12882-015-0189-z.

The original article can be found online at https://doi.org/10.1186/s12882 015-0189-z.

* Correspondence: s.fraser@soton.ac.uk

${ }^{1}$ Academic Unit of Primary Care and Population Sciences, Faculty of Medicine, University of Southampton, South Academic Block, Southampton General Hospital, Tremona Road, Southampton, Hampshire SO16 6YD, UK Full list of author information is available at the end of the article

(c) The Author(s). 2020 Open Access This article is licensed under a Creative Commons Attribution 4.0 International License, which permits use, sharing, adaptation, distribution and reproduction in any medium or format, as long as you give appropriate credit to the original author(s) and the source, provide a link to the Creative Commons licence, and indicate if changes were made. The images or other third party material in this article are included in the article's Creative Commons licence, unless indicated otherwise in a credit line to the material. If material is not included in the article's Creative Commons licence and your intended use is not permitted by statutory regulation or exceeds the permitted use, you will need to obtain permission directly from the copyright holder. To view a copy of this licence, visit http://creativecommons.org/licenses/by/4.0/. The Creative Commons Public Domain Dedication waiver (http://creativecommons.org/publicdomain/zero/1.0/) applies to the data made available in this article, unless otherwise stated in a credit line to the data. 


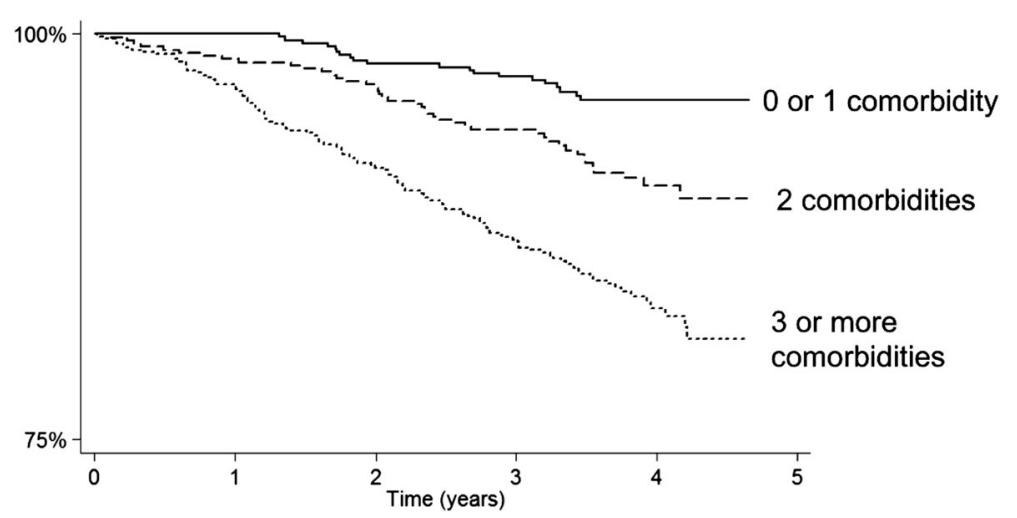

Fig. 1 Kaplan Meier plot showing cumulative survival (all-cause mortality) by comorbidity status. Footnote to Fig. 1: Please note that the $x$ axis does not cross the y axis at $0 \%$ 